\title{
Analysis of the effects of changes in Spanish auditing regulation on audit quality and its differential effect depending on the type of auditor
}

\author{
Elena Cabal-García ${ }^{a}$, Javier De-Andrés-Suarez ${ }^{\mathrm{b}}$, Carlos Fernández-Méndez ${ }^{\mathrm{c}}$
}

a) b) Departamento de Contabilidad, Facultad de Economía y Empresa, Universidad de Oviedo, Oviedo, España

c) Departamento de Administración de Empresas, Facultad de Economía y Empresa, Universidad de Oviedo, Oviedo, España

${ }^{a}$ Corresponding author.

E-mail address: ecabalg@uniovi.es

\section{A R T I C LE IN F O}

\section{Article history:}

Received 16 July 2018

Accepted 16 Jan 2019

Available online 1 July 2019

\section{JEL classification:}

M42

\section{Keywords:}

Audit quality

Big4 auditors

Discretionary accruals

Audit regulation

Códigos JEL

M42

Palabras clave:

Calidad de la auditoría

Auditores Big4

Ajustes por devengo

Rjustes por devengo

\section{A B S T R A C T}

The objective of this paper is to provide evidence on the effect of the reforms of the Spanish auditing legislation, enacted in 2002, 2010 and 2015, on audit quality. More specifically, we study whether the reforms had a differential effect depending on the type of auditor. To this end, the auditors were classified according to their size. We analyzed the specific case of non-financial listed Spanish companies which are considered as Public Interest Entities (PIEs). The main results indicate that none of the reforms caused an improvement in financial reporting quality. This could mean that legal reforms per se are not sufficient to achieve the intended objectives in countries with weak legal enforcement, as is the case of Spain. Because of this, it may be necessary to implement mechanisms to encourage auditors to apply the new rules.

(C)2019 ASEPUC. Published by EDITUM - Universidad de Murcia. This is an open access article under the CC BY-NC-ND license (http://creativecommons.org/licenses/by-nc-nd/4.0/).

Análisis de los efectos de los cambios de la regulación auditora española en la calidad de la auditoría y de su efecto diferencial en función del tipo de auditor

R E S U M E N

El objetivo de este trabajo es aportar evidencia sobre el efecto de las reformas de la legislación auditora española, efectuadas en 2002, 2010 y 2015, sobre la calidad de la auditoría y, más concretamente, sobre si las mismas tuvieron un efecto diferencial en función del tipo de auditor. Para ello, los auditores fueron clasificados en función de su tamaño. Se analizó el caso concreto de las empresas españolas cotizadas no financieras, colectivo que tiene la consideración de Entidades de Interés Público (EIP). Los resultados principales indican que ninguna de las reformas causó mejoras en la calidad de la información financiera Esto podría significar que las reformas legales per se no son suficientes para lograr los objetivos previstos en países con débil aplicación legal, como es el caso de España. Por ello, podría ser necesario implementar mecanismos para alentar a los auditores a aplicar las nuevas reglas.

(C)2019 ASEPUC. Publicado por EDITUM - Universidad de Murcia. Este es un artículo Open Access bajo la licencia CC BY-NC-ND (http://creativecommons.org/licenses/by-nc-nd/4.0/). 


\section{Introduction}

The first Spanish Audit Law (1988) has been subject to three substantial reforms, in 2002, in 2010 and in 2015. All of them were motivated by the need to increase audit quality, incorporating various measures essentially aimed at reinforcing the independence of the auditor.

The objective of this paper is to provide evidence on the effect of the three reforms of the Spanish auditing legislation on audit quality. Specifically, we studied whether the reforms had a differential effect depending on the type of auditor. This issue is of special interest taking into account the requirements of the 2015 Audit Law.

The reforms seeked to give a response to the need to substantially increase the quality of the audit work carried out for those entities currently known as Public Interest Entities (PIEs). By means of the 2002 reform, auditors of these entities must meet some additional requirements regarding independence. Such requirements were consolidated in the 2010 reform. However, the latest reform, which dates from 2015, and implied the passing of a new Audit Law, went much further and after clearly defining which entities must be considered as PIEs, established a differential regulatory framework for their auditors. Multiple additional requirements in terms of independence, control and transparency of the work were imposed, but they are only required when auditing PIEs.

The requirements of the Law are stricter in the Project of the Royal Decree, which will develop the new Law ${ }^{1}$. This project was released in 2018. It states that to be allowed to audit a PIE, an auditor must have experience in the industry in which the PIE operates.

The latest reform leads to major changes in the Spanish audit market. As far as the audited companies are concerned, it is divided into two types of companies: PIEs and the rest. Regarding auditors, there will also be two types: those who are allowed to perform audits of PIEs and the rest. The first group is required by the regulation to achieve higher standards in terms of independence and competence in order to ensure a higher quality of their work.

These circumstances can create a significant barrier to entry within the audit activity (Gonzalo Angulo and Garvey, 2018, pp. 107-108) and may lead to greater market concentration of the PIE segment in the hands of Big4 and secondtier auditors. This is because it seems difficult for many individual auditors and small audit firms to be able to meet the experience requirements necessary to audit these types of companies. This result would not be in accordance with the objectives pursued by the regulations, which include the revitalization of the audit market by making it easier for small audit firms to grow.

In addition, the separation of the auditors into two categories according to whether or not they are allowed to audit PIEs can cause not only differences in the audit quality at inter-firm level, but also at intra-firm level. This is because incremental requirements are only applied to auditors when they perform work for PIEs.

As indicated by Gómez Aguilar et al., (2018), this latest reform will involve high costs for the audit market, but the law was passed without sufficient time to assess its possible effects on the users of accounting information.

To develop the research work, we classified the auditors according to their size, which is the division most commonly

\footnotetext{
${ }^{1}$ Draft of the Royal Decree which develops Law 22/2015, of July 20, on Auditing. This regulation will come into force on the July 1 following its publication.
}

used in previous literature. Traditionally, it has been considered that audit quality may vary depending on auditor size and Big audit firms are supposed to provide higher audit quality than non-Big ones, because they have greater reputational capital to maintain, greater level of specialization, greater public visibility, and they are exposed to greater litigation risk, all of which are factors that help to increase the quality of the audit work.

The analysis of the Spanish case is especially interesting because Spain is a code-law country with low risk of litigation and with relatively weak investor protection (La Porta et al., 1998, Cano Rodríguez, 2007). These characteristics define a framework of low risk for the auditor, so one would not expect Big auditors to exert more control over customers than non-Big ones. Consequently, we decided to analyze the specific case of non-financial listed Spanish companies, which are considered as PIEs, to combine a low-risk environment for the auditor with a type of audited company for which the auditor's failure is more likely to be discovered and punished. This implies a greater reputational risk for the auditor that may induce Big auditors to provide higher quality audits.

The results obtained indicate that in Spain none of the aforementioned changes in the audit regulation have led to significant differences between the quality of the audits by Big firms and that of non-Big auditing companies.

The rest of the paper is structured as follows: Section 2 reviews prior literature that investigates the relationship between the size of the auditor and audit quality. Section 3 discusses the legislative changes that took place in Spain in 2002, 2010 and 2015. Section 4 formulates the hypothesis. Section 5 explains the design of the empirical research work, detailing the sample, the variables, and methodology. Section 6 discusses the main results. Section 7 contains a series of extended analyses, which we carried out in order to complete the results laid out in section 6 . Finally, section 8 sets out the conclusions of the research, as well as some practical implications, the limitations of our work, and some future avenues of research.

\section{Background: Evidence on auditor size and audit quality}

Audit quality is regarded as one of the factors that affects the reliability of accounting information. Audit quality is positively correlated with auditor competence and independence (DeAngelo, 1981), as in their absence audited financial statements are unreliable.

Audit quality is measured using different proxies such as restatements, accounting and auditing enforcement actions, auditor opinion, and especially earnings quality, measured by accruals.

Traditionally, it has been considered that audit quality may vary depending on auditor size. Specifically, Big audit firms are supposed to provide higher audit quality than non-Big ones.

Prior literature offers two possible explanations for the existence of a positive relationship between audit quality and auditor size. First, the reputational theory proposed by DeAngelo (1981), which postulates that Big auditors have greater incentives to develop quality audits because the bigger the audit firm, and the more diversified its market, the stronger the image of independence and reputation they transmit to their clients will be. At the same time, a Big audit firm will be less affected by the loss of customers unsatisfied with the auditor's work. In addition, maintaining their reputation can both retain customers and attract new ones. 
Besides, it should also be noted that Big auditors are subject to a greater degree of public scrutiny due to the fact that the entities they audit, usually large companies of public interest are too $^{2}$. Financial information of these entities has a great number of potential users, which intensifies the demand for quality. Therefore, a low-quality service by these auditors is easier to detect and has a greater public impact, which affects their reputation to a greater extent.

The other explanation for the relationship between audit quality and auditor size is the deep pockets theory, formulated by Dye (1993). This author defines the depth of auditor pocket as the amount of wealth an audit firm has at the beginning of the year. According to the deep pockets theory, large auditors have more resources, so they are exposed to a greater risk of litigation and regulatory sanctions in the event of audit failure. This will encourage them to monitor the audited company more strictly.

Taking into account that Big auditors have greater reputational capital at stake, are subject to greater scrutiny, and are exposed to greater risk of litigation and punishment due to their deep pockets, Big auditors are expected to constrain managerial opportunism to a greater extent than non-Big ones. Thus, the incentives of the latter to limit clients accounting manipulation are not so high.

The initial studies examined differences between the audit work of Big and non-Big auditors and it is hypothesized that Big auditors provide higher audit quality because, according to the postulates of the reputational theory (DeAngelo, 1981) and the deep pockets theory (Dye, 1993), they have greater incentives and competences to do so.

Prior literature provides a large body of research based on reputational theory. These papers used auditor size (Big vs. non-Big) as a proxy for auditor's quality and tried to assess whether a higher quality of the auditor limits opportunistic earnings management as proxy of audit quality (DeAngelo, 1981, DeFond and Jiambalvo, 1991, Becker et al., 1998, Francis et al. 1999, Balsam et al., 2003, Krishnan, 2003, Bauwhede et al., 2003, Cai et al., 2005, Arnedo et al., 2008, Cano Rodríguez, 2007 and 2010, Cassell et al., 2013). These studies conclude that Big auditors impose stronger restrictions on discretionary or abnormal accruals.

In the same vein, a recent study by Krishnan et al., (2015) provides the first empirical evidence that deep pockets auditors are associated with higher audit quality. It was conducted in China, a country where the risk of litigation against auditors is lower than in other developed markets. They conclude that auditors with greater net assets are not only associated with lower income-increasing discretionary accruals, and with a lower probability of clients reporting small earnings, but also with a higher propensity to issue a modified opinion and with a lower likelihood of clients committing financial fraud.

Nevertheless, we must underline that empirical evidence is not conclusive as there are also a number of research papers that showed that there is no difference between the quality of the audits by Big firms and that of non-Big auditing companies with regard to the effective reduction of earnings management practices. Such evidence was first obtained in Korea (Kim and Hwang, 1998; Park et al., 1999; Jeong and Rho, 2004). Similar results were obtained in European countries

${ }^{2}$ In the case of Spain, we searched in Bureau Van Dijk's SABI (Sistema de Análisis de Balances Ibéricos) database for the auditors who audited the 2017 annual accounts of the entities defined as large in the 2015 Audit Law. $51.15 \%$ of the companies were audited by Big4 firms. We also found that in the same year these auditors audited $90.47 \%$ of the entities which qualify as PIEs due to their size, in accordance with article 15 e) of the Royal Decree, of October 2, 2015, which changed the definition of PIE. such as Belgium, France, Spain, Greece and Turkey. For these countries, no significant differences were observed in the discretionary accruals of firms audited by Big and non-Big audit firms (Vander Bauwhede and Willekens, 2004; Navarro García and Martínez Conesa, 2004; Othman and Zeghal, 2006; Lawrence et al. 2011, De las Heras et al., 2012; Tsipouridou and Spathis, 2012; Yasar, 2013).

Consistent with this statement, the review of previous studies allows us to detect three factors that may influence the incentives of Big auditors to provide higher quality audits: (1) the institutional environment of the country analyzed, (2) the nature of the audited companies, and (3) the type of accounting manipulation considered.

Therefore, in environments where institutional requirements do not demand audit quality services, and the auditor faces lower reputational and litigation risks, auditors become more opportunistic in order to attract and retain new customers (Jeong and Rho, 2004; Francis and Wang, 2008; Chen et al., 2010). In other words, the ability of Big auditors to reduce earnings management is affected by the characteristics of the institutional environment of the country in which the audit work is carried out. Similarly, Krishnan et al., (2015) find that the effect of auditor deep pockets on audit quality is generally stronger in Chinese regions with a stronger legal environment.

Likewise, there are works that show that there is a direct relationship between the auditor's effort to provide quality audits and the probability of being discovered and sanctioned if that is not done (Bannister and Wiest 2001; Maijor and Vanstraelen, 2006; Francis and Wang, 2008).

In this regard, some prior papers confirm that Big auditors provide higher quality audits in the case of listed or large companies (Aguiar Díaz and Díaz Díaz, 2015), or in the case of distressed companies (e.g., see Arnedo et al., 2008, for the case of Spanish unquoted distressed companies). There are also works that conclude that companies audited by Big auditors present lower levels of accounting manipulation aimed at avoiding losses (Cano Rodríguez, 2007 and 2010) or at increasing profits (Kim et al., 2003, Bauwhede et al., 2003).

In both cases, both the nature of the entity and that of the specific practice of manipulation make the auditor's failure have a higher detection risk, encouraging Big auditors to provide higher quality audits.

For the Spanish case, prior research did not find evidence of differences in the quality of audit services provided by Big and non-Big auditors (Navarro García and Martínez Conesa, 2004; De las Heras et al., 2012).

Nevertheless, there are also works that show the opposite, such as that of Arnedo et al., (2008), which analyzes unquoted Spanish companies, those of Cano Rodríguez (2007, 2010) that analyze specific accounting manipulation practices to avoid losses, or that of Aguiar Díaz and Díaz Díaz (2015) focused on large companies.

As Francis and Wang (2008) highlight, these discrepancies in the results indicate that the Bigs' behavior is not uniform, but varies according to the incentives of these auditors to perform quality audits assuming the risk of dismissal. Large auditors act opportunistically, producing quality audits when faced with high-risk situations. Otherwise, the incentives of both Big auditors and non-Big ones can make the preservation of the client prevail over the provision of a higher quality service (Cano Rodríguez, 2007).

Hence the success of the audit process is largely conditioned by auditor incentives for competence and independence, and they are determined by factors such as risk of reputation and risk of litigation and regulatory concerns (Kim et 
al., 2003, Boone et al., 2010). Thus, variation across auditorst' incentives must lead to variation in audit quality (DeFond and Zhang, 2014, p. 280).

In this regard, the assessment of whether legislative changes in audit regulation lead to improvements in audit quality and whether there is a differential effect depending on the type of auditor is an interesting research topic. For this reason, it was chosen as the main objective of our research.

\section{Analysis of the reforms of the spanish audit regulation}

Audit of financial statements was first regulated in Spain through the Law on Auditing ("Ley de Auditoría de Cuentas" - LAC), which was passed in 1988. Since then, this law has undergone three relevant reforms aimed at increasing the quality of the audit work. The first one was in 2002, through the Financial Law (*Ley Financiera*, 2002). The second and the third ones occurred in 2010 and 2015, and were motivated by the need to adapt the Spanish regulation to the Directives of the European Union (hereafter EU).

As auditor independence is a very relevant issue, the rules that govern it have been substantially modified in all the reforms. However, and due to the different underlying philosophies, the modifications were very different in nature.

Specifically, the Spanish Financial Law (2002) was passed with the objective to implement the principles that inspired the American Sarbanes-Oxley Act (2002). The main aim of both laws was to restore investor confidence in the markets after the serious worldwide consequences of the Enron scandal. This led to changes in the regulation of auditor independence, which after this reform followed a rigid approach. This new approach brought about a large increase in the number of consulting and other additional services, which are incompatible with the rendering of auditing services.

In addition, this law highlights the need to greatly increase the auditor's public image of independence for the group of entities of bigger size and subject to public oversight. Therefore, mandatory rotation of the signing auditor and their team is imposed.

Because independence is essential to the audit process, the lack of it has always been penalized by the different governing bodies. Accordingly, it has been included in the audit regulation among the punishable conducts, but the punishments have been modified in each one of the legislative reforms.

Under the LAC (1988), the auditor's lack of independence was considered a severe infringement. From the passing of the Spanish Financial Law (2002) onwards, the very severe infringement type was introduced, and lack of independence was considered thus. The legal reform also introduced the prohibition for the auditor to maintain certain relationships -business, financial or management- with the audited company during the three years following the termination of the appointment. In a similar way, the failure to comply with the established requirements for auditor appointment and rotation was also punished. The breach of the aforementioned legal precepts was considered a severe infringement.

With regard to the penalties imposed on audit firms, the major changes of this reform affected the amount of the economic sanctions ${ }^{3}$. These increased substantially, as the maximum applicable fine rose from $10 \%$ to $20 \%$ of the audit fees charged for the last year prior to the imposition of the

${ }^{3}$ Only the sanctions for audit firms were considered. Additionally, all the laws include among the sanctions both temporary and permanent deletion of the auditor from the Official Register of Auditors (Registro Oficial de Auditores de Cuentas - ROAC). The inclusion of the auditor in this register is a necessary condition for the exercise of audit activity. sanction. In addition, the minimum penalty rose from 3,000 euros (LAC, 1988) to 300,000 euros or 6 times the amount perceived for the work in which the infringement was committed.

The second legislative reform was implemented through Law 12/2010, which transposed into the Spanish legal system the European Directive 2006/43/EC, known as the new Eighth Directive.

Law 12/2010 modified the approach of the regulation of auditor independence. Although an explicit list of incompatibilities with the performance of the audit work already existed, the new regulation gave more weight to the auditor's judgment. Specifically, the Law set down general principles of independence and a set of possible threats to them. Nevertheless, auditors were obliged to implement safeguard mechanisms in the audited firm so as to reduce the risk of loss of independence. Regulation also established that in the event that such implementation was not feasible, the auditor should decline to perform the audit work.

Under Law 12/2010, failing to comply with the requisite of independence was still regarded as a serious or very serious infringement. However, major changes in this regulation affected the economic sanctions. There was a large drop in the maximum applicable fines (from $20 \%$ to $6 \%$ of the audit fees charged for the last year prior to the imposition of the sanction). The minimum penalties were also lowered, falling from 300,000 to 24,000 euros in the case of very severe infringements. For the case of severe infringements, the maximum fines dropped from $10 \%$ to $3 \%$ of the audit fees charged and the minimum dropped from 150,000 to 12,000 euros. Moreover, this reform substantially reduced the scope of the auditor's liability, which was strictly limited to the damage inflicted by the auditor.

In this Law the term PIE was introduced for the first time. Entities with significant public relevance, derived from the scale, complexity or nature of their activities, are considered as PIEs. For these entities there is a need to reinforce the reliability of their audited financial statements to a greater extent. The Law maintained the mandatory rotation established in 2002 as an additional measure to safeguard auditor's independence. It also imposed the obligation to publish an annual transparency report.

The 2015 reform involved the passing of a new Law on Auditing, which transposed into the Spanish legal system two standards at EU level: Directive 2014/56/EU of the European Parliament and of the Council, of 16 April 2014, amending Directive 2006/43/EC on statutory audits of annual accounts and consolidated accounts, and Regulation (EU) No 537/2014 of the European Parliament and of the Council of 16 April 2014 on specific requirements regarding statutory audit of public-interest entities (PIEs) and repealing Commission Decision 2005/909/EC.

Unlike the previous reforms, whose main objective was to increase the quality of all the audit works (with just a few specific prescriptions for PIEs' auditors), this latest reform seeked to achieve a higher increase in the quality of the work performed for PIEs than in that done for other entities.

According to this regulation, the concept of PIE is precisely defined and the number of entities classified accordingly as PIEs is substantially reduced. Nevertheless, listed companies were always included among them. Auditors who agree to perform the audit work of these entities are subject to increased requirements with regard to independence from the audited entity. There is a greater number of cases of express incompatibility, more restrictive clauses in relation to the fees, 
and rotation is mandatory at both auditor and firm level ${ }^{4}$.

Compared with the previous regulation, economic sanctions vary only in the case that the infractions are committed in relation to a PIE audit work. In this case the sanction that would apply could be increased up to $20 \%$. In addition, in the event that fines are imposed, the audit company and the auditors responsible for the infraction may be subject to the prohibition to audit PIEs for a period of up to 2 years in the case of severe infringements, and up to 5 years in the case of very severe infringements.

Moreover, the draft of the Royal Decree which develops the 2015 Law on Auditing, states in Article 86 that in order to carry out PIE audits, auditors must have an organizational structure that includes, among other requirements, responsible principal auditors with ample and up-to-date knowledge of the sector or activity in which the audited entity operates, and sufficient experience in the auditing of financial statements of entities of said sector or activity ${ }^{5}$.

Throughout the three reforms, the public oversight of the audit activity in Spain has been gradually strengthened. Furthermore, the public body in charge of the supervision of the audit activity, the Spanish Institute of Accounting and Auditing (Instituto de Contabilidad y Auditoría de Cuentas - ICAC) is required to carry out periodic external quality control of the activity of the audit firms. However, as indicated by García Benau (2016, p.194), it is noteworthy to underline that despite the advances in the normative proposals being unquestionable, it remains to be proven whether more regulation necessarily implies more quality of the audit work.

\section{Hypothesis}

In the present work we analyze a sample of listed Spanish companies in order to assess whether the reforms in the audit regulation cause differences in the audit quality of different types of auditors.

In our study we analyze the particular case of Spain, a code-law country with low risk of litigation and with a relatively weak investor protection (La Porta et al., 1998, Cano Rodríguez, 2007). These characteristics define a framework of low risk for the auditor, so one would not expect Big auditors to exert more control over customers than non-Big ones. In fact, for the Spanish case some studies did not find evidence of differences in the quality of audit services provided by Big and non-Big auditors (Navarro García and Martínez Conesa, 2004, De las Heras et al., 2012).

Nevertheless, there are also works that show the opposite, such as that of Arnedo et al., (2008), which analyzes unquoted Spanish companies, those of Cano Rodríguez (2007, 2010) that analyze specific accounting manipulation practices to avoid losses or that of Aguiar Díaz and Díaz Díaz (2015) focused on large companies.

Thus, prior evidence is inconclusive. In our work, we decided to analyze the specific case of listed Spanish companies for two additional reasons: (1) To combine a low risk environment for the auditor with a type of audited company

\footnotetext{
${ }^{4}$ The effects of mandatory rotation of audit firms on audit quality were tested by Gómez Aguilar et al (2018). Their results show that audit partner rotation does not affect audit quality, and neither does audit firm rotation by itself nor together with audit partner rotation influence audit quality.

${ }^{5}$ This regulation, which has not yet been passed, also specifies that for the auditors performing PIEs audits (excluding PIEs that are issuers of securities admitted to trading in the alternative stock market that belong to the segment of companies in expansion), the minimum experience in the field of auditing must be at least 10 years, and of them, at least 5 in entities operating in the same sector or activity.
}

in which the auditor's incentives to maintain their independence and perform quality audits are higher, and (2) because listed companies are regarded as PIEs.

We extend previous research and test for differences in the effect of auditor's size on audit quality when audit regulation is changed in a country. Prior works studied this issue using a static approach. This was done either by studying a specific country or by comparing a number of countries under an inter-country approach. We adopt a dynamic perspective, and analyze the situation before and after three legislative changes that affect independence and competence requirements, as well as sanctions to auditors.

Spain is a country with a low litigation risk for the auditor and, as mentioned above, the relation between audit quality and auditort's size is expected to be stronger in environments with higher legal development. Nevertheless, as pointed out by Krishnan et al., (2015), litigations are not the only legal threat to auditors' wealth or reputation. In the event of audit failures, Spanish auditors, as well as those from other countries, are exposed to significant economic and reputational costs in the form of public regulatory sanctions prescribed in audit regulation.

The importance of economic sanctions is recognized by Directive 2014/56/EU, which in its motivations section states that the competent authorities of the Member States must be able to impose truly dissuasive fines on auditors who fail to comply with the rules, in order to achieve the intended goal of increasing the quality of the audit work. As an example of dissuasive fines, an amount of up to one million euros or more is proposed for the case of individual auditors, and up to a certain percentage of the annual income earned in the previous financial year for the case of audit firms. In addition, it is emphasized that this objective will be better achieved by adapting the fine to the financial situation of the infractor.

As stated in the previous section, although the sanctions have been reformed over time, in no case do they meet the requirements laid out by this Directive to fulfill the condition of being dissuasive. In addition, in the case of audit firms, the percentages to determine the fines are not calculated based on the total income of the firm, but on the amount of the audit fees. This can make the fines less harmful to Big Auditors.

As De las Heras et al., (2012, p. 527) highlight, the real risk to which Spanish auditors are exposed is precisely that of being sanctioned by the ICAC. These authors also indicate that Big auditors may be less (or equally) affected by the risk of being sanctioned than non-Big ones, given that the sanctions will be proportionally less costly.

However, this assertion does not take into account the indirect effects that an economic sanction may cause on an auditor's reputation. In this regard, the reputational damage that may be caused by receiving a sanction could lead to the loss of those clients for which the reputation and brand image of the auditor was one of the determining factors when choosing the auditor, and can limit the attraction of new clients.

In fact, there are prior research works that show that in the case of Spanish companies, the public image of the auditor is one of the determining criteria for their selection (García Benau et al., 2000; Monterrey Mayoral and Sánchez Segura, 2008). Similarly, Palazuelos Cobo et al., (2017) conclude that the continuity of the client when the company is no longer legally obliged to have its financial statements audited is more likely in companies that were being audited by Big Firms. This also supports the hypothesis that the largest audit firms provide a service of greater quality, which even encourages the company to voluntarily continue hiring their services. 
In addition, for the entities analyzed in this research work (listed firms) the incentives of Big Audit Firms to maintain their independence and reputation are reinforced, since for these kinds of firms the auditor's failure is more likely to be discovered and punished.

After the first two reforms, the auditing of listed companies' financial statements (and the rest of the PIEs) could be carried out by any auditor. Although the reforms modified the amount of economic sanctions, the effects of such sanctions, regardless of their amount, are greater for Big auditors than for the rest as their reputation is affected to a greater extent.

In contrast, the 2015 reform aimed to achieve a greater increase in the quality of the audit work for PIEs. So, these are the only kinds of entities for which the amount of the economic sanctions was increased. In addition, for the case of malpractice in the auditing of PIEs, the possibility of a temporary prohibition to audit these types of entities was also introduced.

This additional sanction does constitute a deterrent measure to auditor's malpractice. However, it has a greater effect on Big auditors, whose main source of income in terms of auditing is precisely big companies and PIEs. The serious economic damage they would face in the event of receiving such a sanction will make them maintain their reputation and perform higher quality audits.

On the other hand, the draft of the Royal Decree which develops the 2015 Law on Auditing requires auditors to prove relevant experience to be able to audit PIEs. Big audit firms are structured along industry lines and invest significant resources to develop industry expertise (Solomon et al., 1999). Specialization is usually proxied as industry market share, so Big audit firms are specialists at national level because they dominate most industries.

Specialized auditors have more specific knowledge about their clients' practices than non-specialist ones, so they are supposed to be more effective in detecting industry-specific errors and in restricting earnings management. They also have more incentives to protect their reputation by resisting client pressure for greater discretion (Reynolds and Francis, 2000).

In addition, specialized auditors are also associated with high financial quality, because they better constrain the managementt's ability to manipulate earnings. This was evidenced for the case of auditors that are specialists at national level (Balsam et al., 2003, Krishnan, 2003). In short, the requirements of current regulation in terms of competence can also motivate Big auditors to perform a higher quality audit work.

Consequently, we propose a hypothesis regarding the type of auditor and the increase in audit quality after these three reforms. We also took into account that prior studies aimed at testing whether the quality of the auditor is a contributing factor to reduce accounting manipulation are based on the premise that the quality of the auditor should have the effect of a higher financial reporting quality. With this in mind, as proxies of audit quality we will use different measures of accruals and formulate the following hypothesis:

H1: The entry into force of the Financial Law (2002), Law $12 / 2010$, and the Audit Law (2015) caused a bigger reduction in discretionary accruals for the case of companies audited by Big auditors than for companies audited by the rest of the auditors.

We examined the financial statements of non-financial listed Spanish companies and their audit reports in the periods before and after each legal reform. Two years prior to and after each reform were considered in order to check the moderating or immediate effect of the period after the change in the regulation between the type of auditing firms and accruals.

\section{Design of the empirical study}

\section{Sample}

As indicated above, the main purpose of this paper is to examine whether the entry into force of legal reforms aimed at improving audit quality have a differential effect depending on auditort's size.

We analyze the case of Spain, a country where the reduced risk of litigation against the auditor may reduce the incentives of the Big auditors to provide higher quality audits. However, we will specifically analyze the case of listed companies, a group that could increase the incentives of Big audit firms to preserve their reputation by providing higher quality audits. This is because the greater degree of scrutiny to which these entities are subject makes any irregularity in their accounting information or in the work of the auditors more likely to be discovered. Furthermore, in these companies such irregularities also have a greater public impact (Cano Rodríguez, 2007).

As discussed earlier, and following previous research, we consider the effects of auditor size (Big vs. non-Big) on audit quality and use discretionary accruals as proxies of audit quality. We decided to use this variable as it allows a sample size bigger than with other proxies of audit quality such as the propensity to issue a modified audit opinion (MAO) or a going concern (GC) opinion. However, we also considered them for our extended analysis ${ }^{6}$.

We examined the audit reports and the financial statements of non-financial listed Spanish companies in the twoyear periods before and after each legal reform. For the 2002 reform, the data corresponding to the pre-reform period is collected from 2000 and 2001, and the data of the postreform period is collected from 2003 and 2004. A similar approach has been followed for the 2010 and the 2015 reforms. It is noteworthy that our study measures the moderating or immediate effect of the passing of each of the reforms on audit quality, and not the long-term effect of each one of them until the next reform is passed.

Our sample of study is formed by non-financial companies listed at the Madrid stock Exchange and have been has been gathered from the registers of audited financial reports deposited in the CNMV (Comisión Nacional del Mercado de Valores) by Spanish listed companies. Details on the auditor identity and the outcome of the audit work has been collected from the CNMV repository. The financial data necessary to build our measures of abnormal accruals have been collected from the Bureau Van Djik's SABI database. The rest of financial information necessary to build the control variables of our estimation models has been obtained from SABI

\footnotetext{
${ }^{6}$ However, the variable "discretionary accruals" has limitations. Although high accruals may proxy for the poor quality of financial statements, they may not arise from generally accepted accounting principles (GAAP) violations. Besides, accruals tend to have high measurement error and even bias (DeFond and Zhang, 2014). For this reason, other variables such as restatements could be a better proxy of financial quality. Restatements are violations of GAAP that indicate audit failure and consequently a low quality audit. Additionally, they have a relatively low measurement error and there is evidence that auditors characteristics are associated with client restatements (Chin and Chi, 2009, Francis and Yu, 2009). Nevertheless, the examination of our sample data reveals that there is only a small number of restatements in the time span analyzed. Therefore, we decided not to use this variable.
} 
Table 1

Distribution of audit reports by auditor type and year

\begin{tabular}{ccccccccccccc}
\hline \multicolumn{3}{c}{ 2002 Reform } & \multicolumn{4}{c}{ 2010 Reform } & \multicolumn{3}{c}{ 2015 Reform } \\
\hline \multirow{2}{*}{ year } & $\begin{array}{c}\text { No } \\
\text { Big4 }\end{array}$ & Big4 Total & year & $\begin{array}{c}\text { No } \\
\text { Big4 }\end{array}$ & Big4 & Total & year & $\begin{array}{c}\text { No } \\
\text { Big4 }\end{array}$ & Big4 & Total \\
\hline 2000 & 17 & 88 & 105 & 2008 & 19 & 103 & 122 & 2013 & 22 & 114 & 136 \\
2001 & 16 & 95 & 111 & 2009 & 14 & 107 & 121 & 2014 & 21 & 110 & 131 \\
2003 & 16 & 100 & 116 & 2011 & 13 & 104 & 117 & 2016 & 18 & 96 & 114 \\
2004 & 20 & 105 & 125 & 2012 & 21 & 105 & 126 & 2017 & 16 & 90 & 106 \\
Total & $\mathbf{6 9}$ & $\mathbf{3 8 8}$ & $\mathbf{4 5 7}$ & Total & $\mathbf{6 7}$ & $\mathbf{4 1 9}$ & $\mathbf{4 8 6}$ & Total & $\mathbf{7 7}$ & $\mathbf{4 1 0}$ & $\mathbf{4 8 7}$ \\
\hline
\end{tabular}

Table 2

Dependent variables in the study

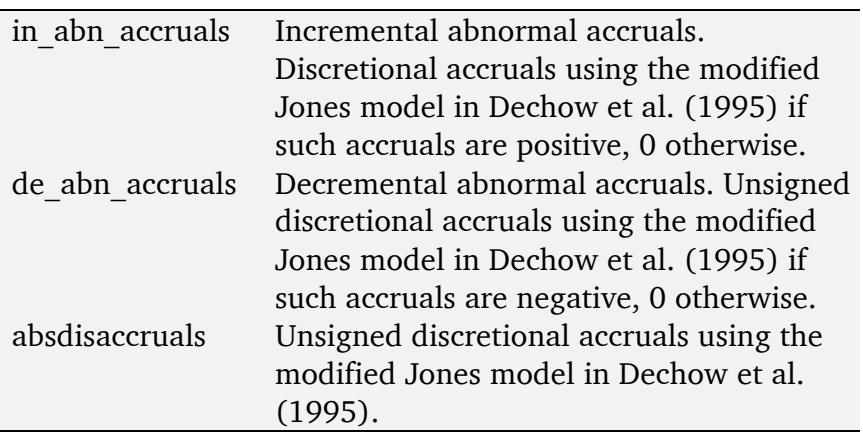

This table presents, for each of the dependent variables in the study, the code which will be used to refer to it in the subsequent tables, and a definition explaining the way it was measured.

and the registers of the CNMV. Finally, the number of foreign subsidiaries used in the instrumentation of the Big4 indicator has been collected from SABI.

The number of audit reports in our sample of study issued by big4 and non big4 audit detailed by year is shown in table 1.

As it can be seen from data in table 1, Big4 auditors clearly dominates the market of audit services for listed companies with a share surrounding $85 \%$ in most years and reaching a maximum share of $88 \%$ in 2009 and 2011. With number of non financial companies ranging from 105 in year 2000 to a maximum of 136 in 2013 the population of Spanish listed companies is well represented with the only exception of financial companies.

\section{Variables}

As dependent variables for our models, first we considered three measures of accruals:

(1) Unsigned incremental discretionary or abnormal accruals.

(2) Unsigned decremental discretionary or abnormal accruals.

(3) Unsigned discretionary or abnormal accruals.

To calculate the discretionary accruals, we followed an extension of the cross-sectional Jones (1991) model used in Dechow et al., (1995). The description of such procedure can be seen in Appendix A. As previous research supports the notion that auditors are more concerned with incomeincreasing earnings management (Abbott et al., 2006), we separated the cases for which we found abnormal accruals causing an increase in results (incremental abnormal accruals) from those causing a reduction (decremental abnormal accruals).
Table 3

Independent variables in the study

\begin{tabular}{|c|c|}
\hline Big4 & $\begin{array}{l}\text { Dummy variable that equals one if the } \\
\text { auditing firm is one of the Big } 4 \text { auditing } \\
\text { companies and zero otherwise }\end{array}$ \\
\hline ar & $\begin{array}{l}\text { Dummy variable that equals one if the } \\
\text { observation corresponds to a period after } \\
\text { the change in the regulation and zero if the } \\
\text { measurements were made before the } \\
\text { reform. }\end{array}$ \\
\hline Big4 $\times$ ar & Interaction term (Big4 and ar). \\
\hline ind & $\begin{array}{l}\text { Indebtedness, measured through the debt } \\
\text { to total assets ratio. }\end{array}$ \\
\hline fec & $\begin{array}{l}\text { Financial expenses coverage measured } \\
\text { through the profit before interests and taxes } \\
\text { to financial expenses ratio. }\end{array}$ \\
\hline fsize & $\begin{array}{l}\text { Size of the audited firm, measured through } \\
\text { the natural logarithm of the total assets. }\end{array}$ \\
\hline roi & $\begin{array}{l}\text { Profitability of the company measured } \\
\text { through the return on investment (ROI) } \\
\text { ratio. }\end{array}$ \\
\hline
\end{tabular}

This table presents, for each of the independent variables in the study, the code which will be used to refer to it in the subsequent tables, and a definition explaining the way it was measured.

We also computed the absolute value of the abnormal accruals (both incremental and decremental, unsigned discretionary accruals), which is considered a good indicator of the combined effect of the decision to alter the results upwards or downwards (Warfield et al., 1995).

These kinds of indicators have been used in prior works related to this issue such as Navarro García \& Martínez Conesa (2004), Kwon et al. (2007), Tsipouridou and Spathis (2012), De las Heras et al., (2012), and Yasar (2013), among others.

Table 2 contains a summary of the dependent variables in our models and the code we will use hereafter to refer to them.

With regard to the independent variables, we included the indicators needed to test whether the formulated hypothesis holds. First, we considered a dummy variable that indicates whether the observation corresponds to a company audited by a Big auditor. A number of prior studies have included a Big4 dummy as proxy of auditor size (i.e., Cano Rodríguez, 2007; Arnedo et al., 2008; Boone et al., 2010; Yasar, 2013; Aguiar Díaz and Díaz Díaz, 2015, among many others).

We also included another dummy indicating if the observation is from a period before or after each legal reform. Pre/post-reform variables have been considered in some prior studies (e.g., De las Heras et al., 2012). Then, we calculated the interaction of the period and the Big4 dummies. This interaction term was used to test the hypothesis, which, as noted earlier, is aimed at assessing whether each of the legal reforms of auditing in Spain had a differential effect on audit quality depending on the type of auditor.

In addition to the variables used to test the hypothesis, we included in the models a number of control variables which may eventually have an effect on the dependent variables in the models (the discretionary accruals). These variables are proxies of the level of indebtedness, financial expenses coverage, firm size, and profitability.

The level of indebtedness was included in prior studies (Vander Bauwhede and Willekens, 2004; Maijoor and Vanstraelen, 2006; Cano Rodríguez, 2007; Kwon et al., 2007; Tsipouridou and Spathis, 2012, De las Heras et al., 2012, Yasar, 2013, among others) because highly leveraged firms may have greater incentives for earnings management, either 
Table 4

Discretional accruals means for the periods surrounding the legal reforms

Panel A: Discretional accruals means for the periods surrounding the 2002 reform

\begin{tabular}{lccccccc}
\hline & \multicolumn{3}{c}{ Big4=0 } & \multicolumn{3}{c}{ Big4=1 } \\
\hline & $\operatorname{ar}=0$ & $\operatorname{ar}=1$ & Difference & ar=0 & ar=1 & Difference \\
\hline in_abn_accruals & 0.091 & 0.058 & 0.033 & 0.079 & 0.044 & $0.035^{* * *}$ \\
de_abn_accruals & 0.245 & 0.342 & -0.097 & 0.203 & 0.285 & -0.082 \\
absdisaccruals & 0.336 & 0.362 & -0.026 & 0.291 & 0.304 & -0.013 \\
& & & & & & \\
\hline
\end{tabular}

$p<0.10,{ }^{* * *} p<0.05, " * * * * 0.01$

Panel B: Discretional accruals means for the periods surrounding the 2010 reform

\begin{tabular}{lcccccc}
\hline & \multicolumn{5}{c}{ Big4=0 } & \multicolumn{3}{c}{ Big4=1 } \\
\hline & $\operatorname{ar}=0$ & $\operatorname{ar}=1$ & Difference & ar=0 & ar=1 & Difference \\
\hline in_abn_accruals & 0.024 & 0.127 & $-0.103^{* * *}$ & 0.031 & 0.1 & $-0.069 * * *$ \\
de_abn_accruals & 0.063 & 0.139 & -0.076 & 0.052 & 0.087 & $-0.035^{* *}$ \\
absdisaccruals & 0.087 & 0.266 & $-0.179 * * *$ & 0.099 & 0.203 & $-0.104 * * *$
\end{tabular}

${ }^{*} p<0.10, * * p<0.05, * * * p<0.01$

Panel C: Discretional accruals means for the periods surrounding The 2015 reform

\begin{tabular}{lccccccc}
\hline & \multicolumn{3}{c}{ Big4=0 } & \multicolumn{3}{c}{ Big4=1 } \\
\hline & ar=0 & ar=1 & Difference & ar=0 & ar=1 & Difference \\
\hline in_abn_accruals & 0.129 & 0.196 & -0.067 & 0.147 & 0.163 & -0.016 \\
de_abn_accruals & 0.39 & 0.341 & 0.048 & 0.39 & 0.244 & 0.146 \\
absdisaccruals & 0.519 & 0.537 & -0.018 & 0.537 & 0.407 & 0.129
\end{tabular}

" $p<0.10,{ }^{* * *} p<0.05,{ }^{* * * *} p<0.01$

This table presents the winsorized means (winsorized fraction=1) of the three variables used as proxies of discretional accruals. Observations are grouped according to the dummy variables ar and Big4.

income increasing or income decreasing (DeFond and Jiambalvo, 1994; Peasnell et al., 2005, among others). For a more accurate measurement of the impact of indebtedness on management's decisions, we also included in the models an indicator of financial expenses coverage.

Empirical studies have also shown that firm size may have an impact -either positive or negative- on discretionary accruals (Becker et al., 1998; Chung et al., 2002). So, following prior studies (Jeong and Rho, 2004; Maijoor and Vanstraelen, 2006; Cano Rodríguez, 2007; Kwon et al., 2007; Arnedo et al., 2008; Tsipouridou and Spathis, 2012; De las Heras et al., 2012, Yasar, 2013, among others), we included an indicator of the size of the audited firm.

Finally, previous studies have suggested a close positive relationship between profitability and the propensity of the company to have discretionary accruals (e.g., Kothari et al., 2005). So we, as well as other authors (i.e. Maijoor and Vanstraelen, 2006; De las Heras et al., 2012; Aguiar Díaz \& Díaz Díaz, 2015), included in our models a proxy of profitability among the control variables.

Table 3 contains a summary of the independent variables in our models and the code we will use hereafter to refer to them.

Table 4 contain some summary descriptive statistics.

The results provide evidence indicating that neither the 2002 reform nor the 2015 one have significant effects in terms of the evolution of the financial information quality issued by Spanish listed firms. We only observe an statistically significant decrease in the use of incremental abnormal accruals after the 2002 reform which occurs only in the case of firms audited by Big4 auditors. This results would support our hypothesis and would indicate an improvement in the quality of financial reporting after the 2002 reform for firms audited by the Big4 However, panel B shows a general increase in abnormal accruals after the legal reform of 2010. There are statistically significant incraeses in the size of all types of abnormal accruals (i.e. incremental, decremental and unsigned). The 2010 reform seems to have a negative effect in terms of a decrease in the quality of financial reporting. Moreover this effect seems to be particularly intense for small auditors. Finally the 2015 reform seems to produce mixed results allowing an intensification in the use of incremental abnormal accruals especially in the case of small auditors and a reduction in the use of decremental abnormal returns. Nevertheless, none of these variations are statistically significant.

Table 5 shows the correlation matrix. Interestingly enough neither Big4 nor ar are correlated to any of our measures of abnormal accruals. We find evidence that firm size and profitability are negatively related to abnormal accruals while firm's leverage relates positively to abnormal accruals. As expected larger and more profitable companies show higher financial reporting quality while the opposite occurs for more leveraged and consequently riskier companies.

\section{Models}

The main empirical method used in this research is regression analysis. We first estimated a series of pooled Ordinary Least Squares (pooled OLS) regression equations by means of which we calculated the effect of the change in the audit regulation on audit quality. We specifically hypothesized a differential effect depending on auditor size. In order to adjust standard errors for heteroscedasticity and serial correlation we use clustering at the firm level (Petersen, 2009).

Our approach requires the measurement of data before and after the application of the treatment. In our case, as detailed above, the measurement of the proxies of audit quality explained in section 3.2 corresponds to the periods before and after the entry into force of the modifications of the regulatory framework of auditing. For each of the legal reforms, the regression equation that was finally estimated takes the following form:

$Y_{i}=\beta_{0}+\beta_{1} \times$ big $_{i}+\beta_{2} \times \operatorname{ar}_{i}+\beta_{3} \times\left(\right.$ Big $\left._{i} \times a r_{i}\right)+$ $\sum \beta_{k} \times$ control $_{k}+\varepsilon_{i}$ (1)

Where:

$Y_{i}$ is the proxy used to measure the quality of the audit work, that is, the variables measuring discretional accruals. Then, for each of the legislative reforms, we estimated a model for each one of the proxies.

The different $\beta_{i}$ are the coefficients to be estimated. $\beta_{3}$ is the coefficient of interest as it is the coefficient of the composite variable Big $4 \times$ ar which indicates the differential effect of the change in the regulation depending on auditor size.

$\mathrm{Control}_{\mathrm{k}}$ are the indicators included as control variables, namely ind, fec, fsize and roi. Finally, $\varepsilon_{i}$ is the regression residual. In all models standard errors are clustered at firm level.

One concern about the estimation of the model described consists in the potential effect that financial reporting qual- 
Table 5

Correlation matrix of the main variables

\begin{tabular}{|c|c|c|c|c|c|c|c|c|}
\hline & absdisaccruals & de_abn_accruals & in_abn_accruals & ar & big4 & in & fsize & roi \\
\hline de_abn_accruals & $\begin{array}{c}0.9789 \\
(0.0000)\end{array}$ & & & & & & & \\
\hline in_abn_accruals & $\begin{array}{l}0.0189 \\
(0.691)\end{array}$ & $\begin{array}{c}0.1859 \\
(0.0001)\end{array}$ & & & & & & \\
\hline ar & $\begin{array}{l}-0.0262 \\
(0.582)\end{array}$ & $\begin{array}{c}0.0352 \\
(0.4587)\end{array}$ & $\begin{array}{l}0.0465 \\
(0.328)\end{array}$ & & & & & \\
\hline big4 & $\begin{array}{l}-0.0551 \\
(0.2457)\end{array}$ & $\begin{array}{c}0.0445 \\
(0.3492)\end{array}$ & $\begin{array}{l}-0.0475 \\
(0.3175)\end{array}$ & $\begin{array}{l}0.0051 \\
(0.914)\end{array}$ & & & & \\
\hline in & $\begin{array}{c}0.1033 \\
(0.0294)\end{array}$ & $\begin{array}{c}-0.114 \\
(0.0162)\end{array}$ & $\begin{array}{l}-0.0612 \\
(0.1978)\end{array}$ & $\begin{array}{l}-0.1001 \\
(0.0348)\end{array}$ & $\begin{array}{l}-0.0903 \\
(0.0569)\end{array}$ & & & \\
\hline fsize & $\begin{array}{c}-0.1393 \\
(0.0032)\end{array}$ & $\begin{array}{c}0.116 \\
(0.0144)\end{array}$ & $\begin{array}{c}-0.1024 \\
(0.0308)\end{array}$ & $\begin{array}{c}0.0137 \\
(0.7732)\end{array}$ & $\begin{array}{c}0.4629 \\
(0.0000)\end{array}$ & $\begin{array}{c}-0.0961 \\
(0.0427)\end{array}$ & & \\
\hline roi & $\begin{array}{l}-0.1477 \\
(0.0018)\end{array}$ & $\begin{array}{c}0.1489 \\
(0.0016)\end{array}$ & $\begin{array}{c}0.018 \\
(0.7045)\end{array}$ & $\begin{array}{c}0.0757 \\
(0.1106)\end{array}$ & $\begin{array}{l}0.0345 \\
(0.468)\end{array}$ & $\begin{array}{c}0.022 \\
(0.6434)\end{array}$ & $\begin{array}{c}0.0734 \\
(0.1219)\end{array}$ & \\
\hline fec & $\begin{array}{l}-0.0348 \\
(0.4634) \\
\end{array}$ & $\begin{array}{c}0.0236 \\
(0.6191) \\
\end{array}$ & $\begin{array}{l}-0.0519 \\
(0.2742) \\
\end{array}$ & $\begin{array}{c}0.0148 \\
(0.7547) \\
\end{array}$ & $\begin{array}{c}0.0573 \\
(0.2279) \\
\end{array}$ & $\begin{array}{l}-0.0432 \\
(0.363) \\
\end{array}$ & $\begin{array}{c}0.0319 \\
(0.5017) \\
\end{array}$ & $\begin{array}{r}0.1088 \\
(0.0217) \\
\end{array}$ \\
\hline
\end{tabular}

$\boldsymbol{P}$ values in parentheses

ity might have on the probability that a company hires Big4 auditor's services. There is evidence that firms audited by Big4 firms show lower absolute values of abnormal accruals (Becker et al., 1998; Francis et al., 1999). Therefore, firms holding aggressive financial reporting practices might resort to Big4 auditors in order to alleviate this problem or conversely avoid Big4 audit firms to elude strict supervision. We address this potential endogeneity issue by using a twostage approach to control for the effects of audit selection on the firm's financial reporting quality. As a company grows in complexity it becomes more difficult to control (Kinney \& McDaniel, 1989). Therefore, complex firms are more likely to select big audit firms who deliver high quality audit services (Simunic, 1980; Simunic \& Stein, 1987; Hay \& Davis, 2004). We consider one proxies of firm's complexity previously used in the literature: the number of foreign subsidiaries as instrument for the Big4 selection. This variable is strongly and positively correlated with the selection of Big4 auditors and shows no correlation with any of our proxies of financial reporting quality. The first stage binary model of Big 4 auditor selection controls also for other firms' features such as firms profitability, inventories and receivables to total assets, financial leverage and size (Lawrence, Minutti-Meza, and Zhang (2011).

We test if big 4 auditor selection is endogenous by including the residual from the big 4 selection model in the financial reporting quality. If the coefficient on the estimated residual is statistically significant the model suffers from endogeneity bias. In that case we use the predicted probabilities of the Big4 selection as the instrumental variable in the financial reporting quality model. Both OLS and instrumental variable estimations are shown in the next section.

\section{Results}

\section{Reform}

Table 6 shows the results of the regression models estimated to test $\mathrm{H} 1$ for the 2002 reform, that is, whether the entry into force of the Financial Law caused a bigger reduction of discretionary accruals for the case of companies audited by Big firms than for companies audited by the rest of the auditors. Panel A of this table presents results of the pooled-OLS estimation of equation (1) while Panel B shows results using the fitted probabilities of Big4 selection as an instrument.
The examination of the results from panel A in table 6 suggests that auditor size has no effect for any of the proxies of discretionary accruals. However, the models with instrumented Big4 reveals that Big4 auditors are associated with a more intensive use of abnormal accruals. Nevertheless, Big4 auditors are associated with conservative income decreasing earnings management, which should not be classified as aggressive reporting. In addition, in none of the models is the coefficient of ar significantly different from zero at the usual significance levels. Thus, we can conclude that on a global basis the Financial Law did not have an effect on discretionary accruals.

Furthermore, none of the interaction term coefficients (Big4 $\mathrm{x}$ ar) are significantly different from zero. In view of this, the change in the behavior of Big auditors is not significantly different from that of non-Big ones. Therefore, these findings suggest that $\mathrm{H} 1$ does not hold for the case of the 2002 reform and the change in the audit regulation did not have a differential effect on the behavior of Big auditors.

These results are consistent with the findings of prior authors who studied reforms of audit regulation in countries with legal and institutional environments similar to that of Spain, for example Vander Bauwhede and Willekens (2004) for the case of Belgium, Tsipouridou and Spathis (2012) for the case of Greece, and Yasar (2013) for the case of Turkey. They are also consistent with those of Navarro García and Martínez Conesa (2004), who studied accounting manipulation and audit quality in a sample of listed Spanish firms or De las Heras et al., (2012), who analyzed a sample containing both listed and non-listed firms.

However, it is noteworthy that some studies conducted in the Spanish setting (Cano Rodríguez, 2007; 2010) found a significant effect of the type of auditor. The reason for this may lie in the fact that this author included in his samples only non-listed firms. Hence, the effect of changes in audit regulation may greatly differ depending on the type of audited entity.

Finally, we must also remark that none of the control variables we included in the models is significant. We have only found some evidence indicating that firm's size is negatively associated with the use income increasing abnormal accruals and positively associated to income decreasing abnormal accruals. Nevertheless, this relationship is not stable across the different estimations (i.e. models with and without instrumented variables) and it is only partially significant. 
Table 6

Regression models (2002 reform and Big4 versus non-Big4 auditors).

Panel A: Pooled OLS estimations with clustering

(1) (2) (3)

in_abn_accruals de_abn_accruals absdisaccruals

\begin{tabular}{lccc} 
& in_abn_accruals de_abn_accruals & absdisaccruals \\
\hline Big4 & -0.0168 & 0.00551 & -0.00733 \\
ar & $(-0.35)$ & $(0.05)$ & $(-0.07)$ \\
& -0.0380 & 0.131 & 0.0500 \\
Big4 $\times$ ar & $(-0.78)$ & $(0.71)$ & $(0.29)$ \\
& -0.000619 & -0.0891 & -0.0704 \\
ind & $(-0.01)$ & $(-0.43)$ & $(-0.37)$ \\
& 0.0263 & 0.111 & 0.0465 \\
fsize & $(0.63)$ & $(0.69)$ & $(0.30)$ \\
& -0.00185 & 0.0452 & 0.0321 \\
roi & $(-0.31)$ & $(1.67)$ & $(1.35)$ \\
& 0.0617 & -0.160 & -0.119 \\
fec & $(0.64)$ & $(-0.57)$ & $(-0.42)$ \\
& -0.0000771 & -0.000106 & -0.000153 \\
cons & $(-1.24)$ & $(-0.90)$ & $(-1.19)$ \\
& $0.194 *$ & 0.567 & 0.783 \\
& $(1.96)$ & $(0.76)$ & $(1.14)$ \\
\hline$N$ & 457 & 457 & 457 \\
r2_a & 0.0159 & 0.0256 & 0.0301 \\
F & 1.398 & 1.614 & 1.652 \\
p & 0.173 & 0.0935 & 0.0833 \\
N_clust & 102 & 102 & 102 \\
\hline & & &
\end{tabular}

$\boldsymbol{t}$ statistics in parentheses

${ }^{*} p<0.10,{ }^{* *} p<0.05,{ }^{* * *} p<0.01$

Panel B: Estimations with instrumented Big4

(1) (2)

2)

(3)

in_abn_accruals de_abn_accruals absdisaccruals

\begin{tabular}{lccc}
\hline Big4 & 0.205 & $\mathbf{0 . 6 5 0 * *}$ & $\mathbf{0 . 8 6 2 * *}$ \\
(instrumented) & & $(\mathbf{2 . 2 9 )}$ & $\mathbf{( 2 . 3 8 )}$ \\
ar & $(1.50)$ & -0.0152 & 0.132 \\
& -0.0191 & $(-0.03)$ & $(0.33)$ \\
Big4 $\times$ ar & $(-0.18)$ & 0.0969 & -0.150 \\
& -0.0193 & $(0.18)$ & $(-0.32)$ \\
ind & $(-0.15)$ & 0.0325 & -0.0451 \\
& -0.000196 & $(0.21)$ & $(-0.28)$ \\
fsize & $(-0.00)$ & 0.000754 & -0.0151 \\
& $-0.0140 *$ & $(0.03)$ & $(-0.50)$ \\
roi & $(-1.77)$ & -0.380 & -0.363 \\
& -0.00608 & $(-1.15)$ & $(-1.19)$ \\
fec & $(-0.06)$ & -0.0000706 & -0.000124 \\
& -0.0000676 & $(-0.54)$ & $(-0.91)$ \\
cons & $(-1.19)$ & 0.639 & 0.716 \\
& 0.183 & $(0.87)$ & $(1.00)$ \\
\hline$N$ & $(1.57)$ & 457 & 457 \\
r2_a & 457 & 0.0298 & 0.0395 \\
F & 0.0279 & 1.805 & 1.713 \\
P & 2.012 & 0.0522 & 0.0695 \\
$\mathrm{~N}$ clust & 0.0270 & 101 & 101 \\
\hline statistics & 101 & &
\end{tabular}

$\boldsymbol{t}$ statistics in parentheses

$$
{ }^{*} \boldsymbol{p}<0.10,{ }^{* *} \boldsymbol{p}<0.05,{ }^{* * *} \boldsymbol{p}<0.01
$$

Panel A of this table presents results of the pooled-OLS estimation of equation (1) for the 2002 reform and each one of the variables used to measure discretionary accruals. Panel B shows results of estimations for the same equation using the fitted probabilities of Big4 auditor selection as an instrument. Among the independent variables we included the type of auditor (Big4 versus non-Big4). The different models correspond to the equation explained in subsection 5.3. For each one of the coefficients in each equation, we show the parameter estimation and the $t$ statistic (below in parentheses, being $*=\mathrm{p}<0.10,{ }^{* *}=\mathrm{p}<0.05$, and $* * *=\mathrm{p}<0.01$ ). Cells having $\mathrm{p}$ values lower than .10 are displayed in bold typeface. All models include SIC industry dummy variables. Standard errors are clustered at the firm level. We also display for each regression equation the number of observations, the adjusted $\mathrm{r}$ 2, the F statistic and its corresponding $\mathrm{p}$ value and the number of clusters.

\section{Reform}

Table 7 shows the results of the regression models estimated to test $\mathrm{H} 1$ for the 2010 reform, that is, the entry into force of Law 12/2010 caused a differential effect between the audit quality of companies audited by Big auditors and that of firms audited by other auditors. Panel A of this table presents results of the pooled-OLS estimation of equation (1) while Panel B shows results using the fitted probabilities of Big4 selection as an instrument.

Results show that companies audited by Big4 firms seem to have higher incremental accruals. Specifically, being audited by a Big4 firm is associated with an increase of 0.10 and 0.14 in incremental abnormal accruals and unsigned abnormal accruals with respect to companies audited by other auditors.

Regarding the effects of the reform (proxied through the ar variable), results in table 7 suggest that the entry into force of Law 12/2010 caused a significant increase of the incremental and unsigned abnormal accruals. This provides evidence that the reform decreased the quality of the audit work. One possible explanation for the effect of the passing of the Law is that among its provisions there was a reduction of the amount of economic sanctions to auditors. This suggests that the alleviation of the economic effect of the sanctions may hinder the improvement in the financial reporting quality expected from this legal reform.

With regard to the variable used to test the hypothesis, that is, the interaction effect between the type of auditor and the dummy used to indicate the period (Big $4 \times$ ar), it is significant for the case of the incremental discretional accruals. In this case there seems to be a slight positive effect in terms of a lower deterioration of financial reporting quality after the legal reform for firms audited by Big4 auditors. The magnitude of such effect almost compensates the aforementioned effect of the reform, so we can conclude that for the case of Big4 auditors the reform had no effect on audit quality as it had effects only on the work of smaller auditors.

Consequently, we can conclude that our data gives some support to $\mathrm{H} 1$ for the case of the 2010 reform, as for the case of incremental accruals we found a significant difference between the effect of the legal reform in firms audited by Big and non-Big auditors. Again, we must indicate that the results are consistent with those of other authors who addressed this topic in countries with institutional environments similar to that of Spain.

Finally, and regarding the control variables we included in the models, we found evidence consistent with that of the correlation matrix. Big and profitable companies show higher financial reporting quality while the opposite occurs for more leveraged and consequently riskier companies.

\section{Reform}

Table 8 shows the results of the regression models estimated to test $\mathrm{H} 1$ for the 2015 reform, that is, the passing of the 2015 Law on Auditing caused a differential effect between the audit quality of companies audited by Big auditors and that of firms audited by other auditors. Panel A of this table presents results of the pooled-OLS estimation of equation (1) while Panel B shows results using the fitted probabilities of Big4 selection as an instrument.

The examination of the results in table 8 reveals that neither the auditor size nor the period surrounding the reform (before - after) seem to have an effect on any of the three indicators of audit quality. In light of these results, 
Table 7

Regression models (2010 reform and Big4 versus non-Big4 auditors).

Panel A: Pooled OLS estimations with clustering

\begin{tabular}{|c|c|c|c|}
\hline & $(1)$ & $(2)$ & (3) \\
\hline & \multicolumn{2}{|c|}{ in_abn_accruals de_abn_accruals } & absdisaccruals \\
\hline \multirow[t]{2}{*}{ Big4 } & $0.101 * * *$ & 0.0439 & $0.145 * *$ \\
\hline & $(3.86)$ & $(0.79)$ & $(2.57)$ \\
\hline \multirow[t]{2}{*}{ ar } & $0.0339 *$ & 0.0191 & $0.0822 * *$ \\
\hline & $(1.73)$ & $(0.86)$ & $(2.31)$ \\
\hline \multirow[t]{2}{*}{ Big $4 \times$ ar } & -0.0350 & -0.0162 & -0.0529 \\
\hline & $(-1.12)$ & $(-0.27)$ & $(-0.72)$ \\
\hline \multirow[t]{2}{*}{ ind } & 0.00151 & $0.0515 * * *$ & $0.0574 * * *$ \\
\hline & $(0.15)$ & $(6.81)$ & $(5.59)$ \\
\hline \multirow[t]{2}{*}{ fsize } & $-0.0112 * *$ & -0.00861 & $-0.0242 * *$ \\
\hline & $(-2.61)$ & $(-1.31)$ & $(-2.46)$ \\
\hline \multirow[t]{2}{*}{ roi } & -0.116 & $-0.183^{* *}$ & $-0.349 * * *$ \\
\hline & $(-0.89)$ & $(-2.22)$ & $(-3.04)$ \\
\hline \multirow[t]{2}{*}{ fec } & -0.00000123 & -0.000000455 & -0.00000210 \\
\hline & $(-1.62)$ & $(-0.39)$ & $(-1.32)$ \\
\hline \multirow[t]{2}{*}{ _cons } & $0.166^{* * * *}$ & 0.0986 & $0.291 * * *$ \\
\hline & $(3.11)$ & $(1.16)$ & $(2.62)$ \\
\hline$N$ & 486 & 486 & 486 \\
\hline r2_a & 0.0496 & 0.0799 & 0.0467 \\
\hline $\mathrm{F}$ & 7.048 & 31.52 & 15.28 \\
\hline $\mathrm{p}$ & $1.20 \mathrm{e}-10$ & $5.08 \mathrm{e}-35$ & $3.01 \mathrm{e}-21$ \\
\hline N_clust & 131 & 131 & 131 \\
\hline
\end{tabular}

$\boldsymbol{t}$ statistics in parentheses

" $p<0.10,{ }^{* * *} p<0.05,{ }^{* * * *} p<0.01$

Panel B: Estimations with instrumented Big4

\begin{tabular}{|c|c|c|c|}
\hline & (1) & (2) & (3) \\
\hline & in_abn_accruals & de_abn_accruals & absdisaccruals \\
\hline Big4 & $0.258 * *$ & -0.0447 & $0.358 *$ \\
\hline & $(2.00)$ & $(-0.37)$ & $(1.91)$ \\
\hline ar & $0.243 * * *$ & 0.0264 & $0.405 * *$ \\
\hline & (2.67) & $(0.24)$ & $(2.00)$ \\
\hline Big $4 \times$ ar & $-0.199 * *$ & 0.00414 & -0.354 \\
\hline & $(-2.02)$ & $(0.03)$ & $(-1.58)$ \\
\hline ind & 0.00229 & $0.0512 * * *$ & $0.0562 * * *$ \\
\hline & $(0.22)$ & $(5.83)$ & (5.16) \\
\hline fsize & $-0.0158 *$ & -0.00550 & $-0.0268 * *$ \\
\hline & $(-1.97)$ & $(-0.67)$ & $(-2.42)$ \\
\hline roi & -0.149 & $-0.170 *$ & $-0.369 * * *$ \\
\hline & $(-0.99)$ & $(-1.88)$ & $(-2.86)$ \\
\hline fec & 0.00000232 & -0.00000133 & 0.00000252 \\
\hline & (1.22) & $(-0.89)$ & (0.99) \\
\hline _cons & 0.0261 & 0.119 & 0.0901 \\
\hline & $(0.55)$ & (1.66) & $(0.84)$ \\
\hline$N$ & 486 & 486 & 486 \\
\hline r2_a & 0.0539 & 0.0798 & 0.0473 \\
\hline $\mathrm{F}^{-}$ & 3.53 & 50.47 & 29.00 \\
\hline $\mathrm{p}$ & 0.0091 & 0.0000 & 0.0000 \\
\hline N_clust & 131 & 131 & 131 \\
\hline
\end{tabular}

A of this table presents results of the pooled-OLS estimation of equation (1) for the 2010 reform and each one of the variables used to measure discretionary accruals. Panel B shows results of estimations for the same equation using the fitted probabilities of Big4 auditor selection as an instrument. Among the independent variables we included the type of auditor (Big4 versus non-Big4). The different models correspond to the equation explained in subsection 5.3. For each one of the coefficients in each equation we show the parameter estimation and the t statistic (below in parentheses, being $*=\mathrm{p}<0.10, * *=\mathrm{p}<0.05$, and $* * *=\mathrm{p}<0.01$ ). Cells having $\mathrm{p}$ values lower than .10 are displayed in bold typeface. All models include SIC industry dummy variables. Standard errors are clustered at the firm level. We also display for each regression equation the number of observations, the adjusted $\mathrm{r} 2$, the F statistic and its corresponding $\mathrm{p}$ value and the number of clusters.
Table 8

Regression models (2015 reform and Big4 versus non-Big4 auditors).

Panel A: Pooled OLS estimations with clustering

\begin{tabular}{|c|c|c|c|}
\hline & $(1)$ & $(2)$ & (3) \\
\hline & \multicolumn{3}{|c|}{ in_abn_accruals de_abn_accruals absdisaccrual } \\
\hline \multirow[t]{2}{*}{ Big4 } & 0.0714 & 0.138 & 0.209 \\
\hline & $(1.25)$ & $(0.56)$ & $(0.88)$ \\
\hline \multirow[t]{2}{*}{ ar } & 0.0639 & -0.0634 & 0.000546 \\
\hline & $(1.14)$ & $(-0.22)$ & $(0.00)$ \\
\hline \multirow[t]{2}{*}{ Big $4 \times$ ar } & -0.0493 & -0.0350 & -0.0843 \\
\hline & $(-0.85)$ & $(-0.11)$ & $(-0.26)$ \\
\hline \multirow[t]{2}{*}{ ind } & -0.00881 & 0.0835 & 0.0747 \\
\hline & $(-1.55)$ & $(1.28)$ & $(1.16)$ \\
\hline \multirow[t]{2}{*}{ fsize } & $-0.0175 * *$ & -0.0443 & $-0.0618 *$ \\
\hline & $(-2.24)$ & $(-1.22)$ & $(-1.67)$ \\
\hline \multirow[t]{2}{*}{ roi } & 0.00645 & -0.560 & -0.554 \\
\hline & (0.19) & $(-1.29)$ & $(-1.29)$ \\
\hline \multirow[t]{2}{*}{ fec } & $-0.0000184 * * *$ & -0.0000150 & -0.0000334 \\
\hline & $(-3.04)$ & $(-0.78)$ & $(-1.61)$ \\
\hline \multirow[t]{2}{*}{ _cons } & $0.346 * * *$ & $0.823 *$ & $1.169 * *$ \\
\hline & $(4.08)$ & (1.95) & $(2.61)$ \\
\hline$N$ & 487 & 487 & 487 \\
\hline r2_a & 0.0577 & 0.0215 & 0.0353 \\
\hline $\mathrm{F}^{-}$ & 4.253 & 3.416 & 4.540 \\
\hline $\mathrm{p}$ & 0.0000 & 0.0000 & 0.0000 \\
\hline N_clust & 150 & 150 & 150 \\
\hline
\end{tabular}

Panel B: Estimations with instrumented Big4

\begin{tabular}{|c|c|c|c|}
\hline & $(1)$ & $(2)$ & (3) \\
\hline & \multicolumn{3}{|c|}{ in_abn_accruals de_abn_accruals absdisaccruals } \\
\hline \multirow[t]{2}{*}{ Big4 } & 0.153 & -0.568 & -0.414 \\
\hline & $(1.57)$ & $(-1.18)$ & $(-0.88)$ \\
\hline \multirow[t]{2}{*}{ ar } & 0.102 & -0.114 & -0.0119 \\
\hline & $(0.89)$ & $(-0.15)$ & $(-0.01)$ \\
\hline \multirow[t]{2}{*}{ Big $4 \times$ ar } & -0.157 & 0.565 & 0.409 \\
\hline & $(-1.41)$ & $(1.06)$ & $(0.79)$ \\
\hline \multirow[t]{2}{*}{ ind } & -0.00951 & 0.0805 & 0.0710 \\
\hline & $(-1.64)$ & $(1.26)$ & $(1.13)$ \\
\hline \multirow[t]{2}{*}{ fsize } & $-0.0143 *$ & -0.0401 & -0.0545 \\
\hline & $(-1.66)$ & $(-0.70)$ & $(-0.91)$ \\
\hline \multirow[t]{2}{*}{ roi } & -0.00156 & -0.570 & -0.572 \\
\hline & $(-0.04)$ & $(-1.28)$ & $(-1.30)$ \\
\hline \multirow[t]{2}{*}{ fec } & $-0.0000180 * * *$ & -0.0000136 & -0.0000317 \\
\hline & $(-3.14)$ & $(-0.71)$ & $(-1.47)$ \\
\hline \multirow[t]{2}{*}{ _cons } & $0.287 * * *$ & $0.998 * *$ & $1.285 * *$ \\
\hline & (3.10) & $(2.07)$ & $(2.55)$ \\
\hline$N$ & 487 & 487 & 487 \\
\hline r2_a & 0.0549 & 0.0219 & 0.0340 \\
\hline $\mathrm{F}$ & 3.954 & 3.991 & 5.766 \\
\hline $\mathrm{p}$ & 0.0000 & 0.0000 & 0.0000 \\
\hline N_clust & 150 & 150 & 150 \\
\hline
\end{tabular}

$\boldsymbol{t}$ statistics in parentheses

$p<0.10,{ }^{* * *} p<0.05,{ }^{* * * *} p<0.01$

Panel A

of this table presents results of the pooled-OLS estimation of equation (1) for the 2015 reform and each one of the variables used to measure discretionary accruals. Panel B shows results of estimations for the same equation using the fitted probabilities of Big4 auditor selection as an instrument. Among the independent variables we included the type of auditor (Big4 versus non-Big4). The different models correspond to the equation explained in subsection 5.3. For each one of the coefficients in each equation, we show the parameter estimation and the $t$ statistic (below in parentheses, being $*=p<$ $0.10,{ }^{* *}=\mathrm{p}<0.05$, and $* * *=\mathrm{p}<0.01$ ). Cells having $\mathrm{p}$ values lower than .10 are displayed in bold typeface. All models include SIC industry dummy variables. Standard errors are clustered at the firm level. We also display for each regression equation the number of observations, the adjusted $\mathrm{r}$, the F statistic and its corresponding $\mathrm{p}$ value and the number of clusters. 
there is evidence neither of differentiated behavior of Big4 auditors nor of the effectiveness of the law's entry into force.

What is more, the interaction between auditor size and period (Big4 $\times$ ar) is not significant in any of the models. So, it is observed that for the case of the 2015 reform, H1 does not hold. With regard to the control variables, only firm size and interest coverage seem to have a significant and positive effect on audit quality. Large firms and those with high interest coverage ratios show lower levels of income increasing abnormal accruals. This is consistent with large firms being under intense public scrutiny and solvent firms lacking incentives to manipulate their performance indicators.

The results obtained from the analysis of the three reforms indicate that in Spain only the 2010 change in the audit regulation has led to some (albeit weak) difference between the quality of the audits of listed companies performed by Big firms and that of non-Big ones. And in this case, the effect of this legal reform characterized by a decrease in the economic penalties to audit firms, was a deterioration of the firm's financial reporting quality. Nevertheless, this deterioration was lower for firms audited by big auditors.

As for the possible reasons behind the lack of any other relevant effects from the 2002 and 2015 reforms, they can be twofold. First, the Spanish institutional environment offers such a low degree of protection to investors that the regulation of auditing does not really matter. This has an important practical implication which is that the most effective measures for the improvement of the quality of auditing should be those aiming at creating a better institutional environment. In other words, the effective enforcement of the legislation should be guaranteed. Secondly, another possible explanation is that the tightening of legislation and sanctions was not enough to produce changes in behavior and especially changes in the differential behavior of the Big auditing firms versus the rest.

With regard to the comparison with prior research efforts, the lack of differences between Big and non-Big auditors in terms of reduction in earnings management had previously been evidenced for the Spanish case (Navarro García and Martínez Conesa, 2004, De las Heras et al., 2012) as well as for other European countries such as Belgium, France and Greece (Vander Bauwhede and Willekens, 2004; Tsipouridou and Spathis, 2012) and also for other non-European settings as for example Korea (Kim and Hwang, 1998; Park et al., 1999; Jeong and Rho, 2004).

All these countries have a feature in common, namely that they were classified in the second and third clusters in the work by Leuz et al. (2002). The work by Leuz et al. performs a descriptive cluster analysis to identify groupings of countries with similar institutional characteristics and provides descriptive evidence on systematic patterns with regard to earnings management across groups of countries with similar institutional characteristics. The countries were classified into three clusters. The first cluster is characterized by large stock markets, lower ownership concentration, extensive outsider rights, high disclosure, and strong legal enforcement. This cluster includes, among others, USA and the UK. For these countries, prior research has evidenced that the type of auditor has a significant influence on the reduction of earnings management (DeAngelo, 1981; DeFond and Jiambalvo, 1991; Becker et al., 1998; Francis et al., 1999; Bauwhede et al., 2003; Cai et al., 2005). By contrast, second and third clusters comprise several Asian and Southern European countries, including Spain. These countries have smaller stock markets, higher ownership concentration, weaker investor protection, lower disclosure levels and weaker enforcement.
In other words, these countries have an institutional environment with certain characteristics that mean that changing the audit regulation is not enough to improve the quality of the audit work.

\section{Extended Analysis}

To complete the results discussed in the preceding section, we estimated a series of additional analyses. First, we considered as dependent variables other accruals measures: a) the signed discretional accruals using the modified Jones model in Dechow et al., (1995), b) the unsigned discretional accruals adjusted by the industry median value, and c) the natural logarithm of unsigned discretional accruals adjusted by the industry median value. Results confirm the findings discussed in the preceding section.

Secondly, we took into account that managers are likely to rely on income-increasing accruals within 5\% of total assets to attain their earnings goals (Boone et al., 2012; Park, 2015, 2017). So, we used an additional measure of accruals, which is the loss avoidance (LA). We define LA as the use of income-increasing discretionary accruals to avoid reporting a loss. It is a dummy variable equal to 1 if the firmt's premanaged earnings (net income deflated by total assets in the prior fiscal year - discretionary accruals) fall short of zero by less than $5 \%$ of total assets, and 0 otherwise. We estimated a series of logit models, in which LA is the dependent variable and the independent variables are the same as explained in section 5.2. Results of this analysis are also consistent with those reported in section 6 , but disagree with those obtained by Cano Rodríguez $(2007 ; 2010)$. As noted above, the reason for this may lie in the fact that the samples analyzed by this author contain only non-listed firms.

Thirdly, we estimated a series of models considering alternative proxies of audit quality, namely the propensity to issue a modified audit opinion (MAO) and a going concern (GC) opinion. A higher propensity to issue a MAO is viewed as an indicator for higher audit quality (Chen et al., 2010, Krishnan et al. 2015) but this may indicate auditor conservatism instead of higher audit quality (DeFond and Zhang, 2014). We estimated a series of logit models in which we considered as dependent variable a dummy which equals zero in the event of a modified audit opinion, and zero otherwise. As independent variables we considered the same as for the prior analyses. Results confirm the findings discussed in section 6 . With regard to the models where the dependent variable was the propensity to issue a GC opinion, the results confirm also that H1 does not hold.

Finally, we replaced the Big4 dummy by an alternative specification of the type of auditor that specifically takes into account the postulates of the deep pockets theory. So, we included the proxy of the wealth of the audit firm used by Krishnan et al., (2015), which is auditor size (the natural logarithm of the total assets of the auditor ${ }^{7}$ ). According to the deep pockets theory, large auditors have more resources and are exposed to a greater risk of litigation and regulatory sanctions, meaning they have more incentives to increase the quality of the audit work. Results of this additional analysis confirm those in tables 5 to 7 . This is inconsistent with the findings of Krishnan et al., (2015), which provide empirical evidence that deep pockets auditors are associated with higher audit quality. This may be due to the fact that these authors studied the Chinese case, which is characterized by

\footnotetext{
${ }^{7}$ This information was also obtained from the Bureau Van Dijk's SABI (Sistema de Análisis de Balances Ibéricos) database.
} 
a legal and institutional environment different from that of Spain.

\section{Conclusions}

The objective of our work was to provide empirical evidence on the effect of the reforms of the Spanish auditing legislation on audit quality. Specifically, we tried to assess whether they produce a differential effect depending on the size of the auditor (Big4 vs non-Big4). There is a number of prior studies that relate the quality of the audit to the size of the auditor. However, this topic is especially relevant at present, since according to the provisions of the auditing regulation currently in force, only certain types of auditors will be allowed to audit the entities considered as PIEs. Given that Big auditors will comply in all cases with these requirements, it is interesting to check whether these types of auditors in particular are affected to a greater extent by the legal reforms aimed at improving audit quality.

We used as proxy of audit quality several measures of discretionary accruals. Our findings from a sample of PIEs composed of non-financial listed Spanish companies suggest that none of the three reforms of the Spanish auditing legislation (2002, 2010 and 2015) attained an improvement in financial reporting quality or caused a clear differential effect on the quality of work performed by Big auditors compared to the rest.

These results were confirmed when we conducted a series of extended analyses considering other accruals-based indicators and two alternative proxies of audit quality, namely the propensity to issue a modified audit opinion (MAO) and the propensity to issue a going concern (GC) opinion. In order to check the postulates of the deep pockets theory, we also replaced the Big4 dummy by another proxy of auditor size (the total assets of the auditor). No significant differences were found.

As for possible explanations for our results, we must highlight that in our study we analyzed the case of Spain. This is a country with a legal and institutional environment characterized by relatively low levels of litigation risk and investor protection. These factors should discourage the pursuit of higher quality audits by large audit firms. In fact, previous empirical evidence from Spain suggests that the intensity of earnings management practices does not depend on the size of the auditor (Navarro García and Martínez Conesa, 2004; De las Heras et al., 2012).

As regards for the limitations of our research work, which may be also considered as reasons for our findings, we can mention the following: a) As is well known, the Spanish national audit market is characterized by a high degree of concentration in the hands of the Big4 auditors. So, the division we made into Big / non-Big auditors can be problematic in its practical application. b) We compared a limited number of years before and after each reform, that is, only to a limited extent did we assess the moderating effect of the period after the change in the regulation. c) In order to assess the full effects of the latest reform, we will have to wait for the entry into force of the Royal Decree that develops the 2015 Audit Law. d) Lastly, we analyzed only one specific type of PIE, namely the segment of listed firms.

In spite of such limitations, the results have relevant implications for regulators, since the reforms implemented, especially the latest one, are based on the premise that greater requirements to auditors will result in higher audit quality levels. Our findings do not give support to this argument. Moreover, the measures included in the latest reform may produce pernicious effects on the Spanish auditor market, such as a greater concentration of the PIE segment in the hands of the Big4 firms or the incentives to auditors to behave opportunistically, offering different levels of quality depending on the client.

The final conclusion is that in Spain the institutional environment does not allow the audit regulation reforms to be effective in terms of improving the quality of the work of the auditor. In light of this, changes in regulation alone are not sufficient. They need to be accompanied by effective mechanisms to ensure that auditors comply with the standards as intended. The results of our study may be of interest in the context of the EU. Furthermore, they may be extrapolated to other countries with institutional environments similar to Spain.

For all these reasons, we consider that the in-depth study of the effectiveness of the reforms of audit regulation and their differential effect on different types of auditors may be a fruitful avenue of research. As future research work it could be worthwhile to extend the analysis of the reforms considering their effects on different types of entities apart from listed firms. The separate analysis of other types of auditors, such as second tier or specialized ones, is also an interesting research opportunity. These auditors are particularly relevant because, as noted above, the 2015 reform imposed competence requirements and mandatory rotation at firm level to the auditors of PIEs. Therefore, second-tier and specialized auditors are a viable alternative to Big Firms, since both have similar incentives to maintain their independence and reputation (Boone et al., 2010). In fact, there is evidence that the quality of the audit work performed by these firms is similar to that provided by Big4 firms and superior to that of smaller auditors (Chin and Chi, 2009, Boone et al., 2010; Reitchel and Wang, 2010; Chi and Chin, 2011; Cassell et al., 2013; Aguiar Díaz y Díaz Díaz, 2015; Ittonen et al., 2015).

\section{Conflicts of interest}

The authors have no conflicts of interest to declare.

\section{References}

Abbott, L., Parker, S., \& Peters, G. (2006). Earnings management, litigation risk and asymmetric audit fee responses. Auditing: A Journal of Practice \& Theory, 25(1), 85-98.

Aguiar Díaz, I., \& Díaz Díaz, N. (2015). Calidad de la auditoría, Second-Tier y tamaño: su efecto en las empresas fracasadas no cotizadas españolas. Revista Española de Financiación y Contabilidad, 44 (1), 24-46.

Arnedo, L., Lizárraga, F., \& Sánchez, S. (2008). Goingconcern uncertainties in pre-bankrupt audit reports: New evidence regarding discretionary accruals and wording ambiguity. International Journal of Auditing, 12 (1), 25-44.

Balsam, S., Krishnan, J., \& Yang J.S. (2003). Auditor Industry Specialization and Earnings Quality. Auditing: A Journal of Practice \& Theory, 22(2), 71-97.

Bannister, J.W., \& Wiest, D.N. (2001). Earnings management and auditor conservatism: Effects of SEC enforcement actions. Managerial Finance, 27 (12), 51-71.

Bauwhede, H.V., Willikens, M., \& Garemynck, A. (2003). Audit Firm Size, Public Ownership and Firms' Discretionary Accruals Management. International Journal of Accounting, 38(1), 1-22.

Bauwhede, H.V., \& Willikens, M. (2004). Evidence on (the lack of) audit-quality differentiation in the private client seg- 
ment of the Belgian audit market. European Accounting Review, 13(3), 501-522

Becker, C.L., \& Defond, M.L., Jiambalvo, J., \& Subramanyam, K.R. (1998). The Effect of Audit Quality on Earnings Management. Contemporary Accounting Research, 15(1), 124.

Boone, J., Khurana, I., \& Raman, K. (2010). Do the Big4 and the second-tier firms provide audits of similar quality? Journal of Accounting and Public Policy, 29 (4), 330-352.

Boone, J.P., Khurana, I.K., \& Raman, K.K. (2012). Audit market concentration and auditor tolerance for earnings management. Contemporary Accounting Research, 29(4), 11711203.

Cai, C., Zhao, S., \& Huang, Y. (2005). Toward The Effect of Audit Quality on Earnings Management-Empirical Evidence From Manufacturing Enterprises Listed in Shangai Stock Market. Journal of Modern Accounting and Auditing, 1(2), 6980.

Cano Rodríguez, M. (2007). Tamaño del auditor y calidad de la auditoría en las empresas españolas no cotizadas. Revista Española de Financiación y Contabilidad, 36(135), 481507.

Cano Rodríguez, M. (2010). Big Auditors, Private Frirms and Accounting Conservatism: Spanish Evidence. European Accounting Review, 19 (1), 131-159.

Cassell, C.A., Giroux, G., Myers, L., \& Omer, T. (2013). The emergence of Second-Tier auditors in US: Evidence from investor perceptions of financial reporting credibility. Journal of Business Finance \& Accounting, 40 (3-4), 350-372.

Chen, S., Sun, S., \& Wu, D. (2010). Client importance, institutional improvements and audit quality in China: An office and individual auditor level analysis. The Accounting Review, 85(1), 127-158.

Chi, H.Y., \& Chin C.H.L. (2011). Firm versus partner measures of auditor industry expertise and effects on auditor quality. Auditing: A Journal of practice \& Theory, 30(2), 201-229.

Chin, C.L., Chi, H.Y. (2009). Reducing restatements with increased industry expertise. Contemporary Accounting Research, 26(3), 729-765.

Chung, R., Firth, M., \& Kim J.B. (2002). Institutional monitoring and opportunistic earnings management. Journal of Corporate Finance, 8(1), 29-48.

DeAngelo, L. (1981). Auditor Size and Audit Quality. Journal of Accounting and Economics, 3(3), 183-199.

Dechow, P.M., Sloan, R.G., \& Sweeney, A.P. (1995). Detecting Earnings Management. Accounting Review, (70)2, 193225 .

DeFond, M.L., \& Jiambalvo, J. (1991). Incidence and Circumstances of Accounting Errors. Accounting Review, 66(3), 643-655.

DeFond, M.L., \& Jiambalvo, J. (1994). Debt covenant violation and manipulation of accruals. Journal of Accounting and Economics, 17(1-2), 145-176.

DeFond, M., \& Zhang, J. (2014). A review of archival auditing research. Journal of Accounting and Economics, 58(2), 275-326.

De las Heras, E., Cañibano, C., \& Moreira, J.A. (2012). The impact of the Spanish Financial Act (44/2002) on audit quality. Spanish Journal of Finance and Accounting / Revista Española de Financiación y Contabilidad, 41(156), 521-546.

Directive 2006/43/EC of the European Parliament and of the Council of 17 May 2006 on statutory audits of annual accounts and consolidated accounts, amending Council Directives 78/660/EEC and 83/349/EEC and repealing Council Directive 84/253/EEC, Official Journal of the European
Union L 157/87.

Directive 2014/56/EU of the European Parliament and of the Council of 16 April 2014, amending Directive 2006/43/EC on statutory audits of annual accounts and consolidated accounts, Official Journal of the European Union $\mathrm{L}$ 158/196.

Dye, R. (1993). Auditing Standards, Legal Liability and Auditor Wealth. Journal of Political Economy, 101, 887-914.

Francis, J.R., Stokes, D.J., \& Anderson, D. (1999). City markets as a unit of analysis in audit research and the reexamination of Big 6 market shares. Abacus, 35(2), 185-206.

Francis J.R., Maydew, E.L., \& Sparks, H.C. (1999). The Role of the Big 6 Auditors in the Credible Reporting of Accruals. Auditing: a Journal of Practice \& Theory, (18)2, 17-34.

Francis, J.R., \& Wang, D. (2008). The Joint Effect of Investor Protection and Big4 Audits on Earnings Quality Around the World. Contemporary Accounting Research, 25(1), 157-191.

Francis, J.R., \& Yu, M.D. (2009). Big4 office size and audit quality. Accounting Review, 84(5), 1521-1552.

García Benau, M.A., Ruiz Barbadillo E., \& Vico Martínez, A. (2000). Factores que condicionan la elección y el cambio de auditor en la empresa española. Revista de ContabilidadSpanish Accounting Review, 3 (6), 49-80.

García Benau, M.A. (2016): El marco normativo internacional de la auditoría y su repercusión en España. Revista Española de Control Externo, 28(52), 175-196.

Gómez Aguilar, N., Biedma López, E., \& Ruíz Barbadillo, E. (2018). El efecto de la rotación de socio en la calidad de la auditoría. Revista de Contabilidad-Spanish Accounting Review, 21(1), 7-18.

Gonzalo Angulo, J.A., \& Garvey, A.M. (2018): Audit research: some reflections, Revista de Contabilidad-Spanish Accounting Review, 21(2), 107-115.

Hay, D., \& Davis, D. (2004). The voluntary choice of an auditor of any level of quality. Auditing: A Journal of Practice \& Theory, 23(2), 37-53.

Ittonen, K., Johnstone, K., \& Myllymäki, E.R. (2015). Audit Partner Public-Client Specialisation and Client Abnormal Accruals. European Accounting Review, 24(3), 607-633.

Jeong, S.W., \& Rho, J. (2004). Big Six Auditors and Audit Quality: the Korean Evidence. International Journal of Accounting, 39(2), 175-196.

Jones, J. (1991). Earnings Management During Import Relief Investigation. Journal of Accounting Research, 29(2), 193-228.

Kim, M., \& Hwang, I. (1998). The Effect of Audit Quality Difference on Prior Year Adjustments. Korean Accounting Journal, 20(2), 323-359.

Kim, J.B., Ching, R., \& Firth, M. (2003). Auditor Conservative, Asymetric Monitoring and Earnings Management. Contemporary Accounting Research, 20 (2), 323-359

Kinney W., \& McDaniel, L.S. (1989). Characteristics of firms correcting previously reported quarterly earnings.Journal of Accounting and Economics, 11(1), 71-93.

Kothari, S.P.; Leone, A., \& Wasley, C.E. (2005). Performance matched discretionary accrual measures. Journal of Accounting and Economics, 39(1), 163-197.

Krishnan, G. (2003). Does Big 6 Auditor Industry Expertise Constrain Earnings Management? Accounting Horizons Supplement, 1-16.

Krishnan, G.V., Ma, M., \& Yan, W. (2015). Do auditors with a deep pocket provide a high quality audit? WP. 2016 UTS Australian Summer Accounting Conference.

Kwon, S.Y.; Lim C.Y., \& MuiSiang Tan, P. (2007). Legal Systems and Earnings Quality: The Role of Auditor Industry Spe- 
cialization. Auditing: A Journal of Practice \& Theory, 26(2), 25-55.

La Porta, R., LopezdeSilanes, F., Shleifer A., \& Vishny, R.W. (1998). Law and Finance, Journal of Political Economy, 106 (6), 1113-1155.

Lawrence, A., Minutti-Meza, K., \& Zang, P. (2011). Can Big4 versus Non-Big4 differences in Audit Quality proxies be attributed to client characteristics? Accounting Review, 86 (1), 259-286.

Ley 19/1988 de 12 de julio de Auditoría de Cuentas, BOE nž 169.

Ley 44/2002, de 22 de noviembre, de Medidas de Reforma del Sistema Financiero (Ley Financiera- Financial Law), BOE nž 281.

Ley 12/2010, de 30 de junio, por la que se modifica la Ley 19/1988, de 12 de julio, de Auditoría de Cuentas, la Ley 24/1988, de 28 de julio, del Mercado de Valores y el texto refundido de la Ley de Sociedades Anónimas aprobado por el Real Decreto Legislativo 1564/1989, de 22 de diciembre, para su adaptación a la normativa comunitaria, BOE nž 159 .

Ley 22/2015, de 20 de julio, de Auditoría de Cuentas, BOE nž 173.

Leuz, C., Dhananjay, N., \& Wysocki, P.D. (2002). Earnings Management and Investor Protection: an International Comparison. Journal of Financial Economics, 69, 505-527.

Maijoor, S.J., \& Vanstraelen, A. (2006). Earnings management within Europe: The effects of member state audit environment, audit firm quality and capital markets. Accounting \& Business Research, 36 (1), 33-52.

Monterrey Mayoral, J., \& Sánchez Segura, A. (2008). Gobierno corporativo, conflictos de agencia y elección del auditor. Revista Española de Financiación y Contabilidad, XXXVII (137), 113-156.

Navarro García, J.C., \& Martínez Conesa, I. (2004). Manipulación contable y calidad del auditor. Un estudio empírico de la realidad española. Revista Española de Financiación y Contabilidad, 33(123), 1.025-1.064.

Othman, H.B., \& Zeghal. D. (2006) A Study of EarningsManagement Motives in the Anglo-American and EuroContinental Accounting Models: The Canadian and French Cases. International Journal of Accounting, 41, 406-435.

Palazuelos Cobo, E., Montoya del Corte, J., \& Herrero Crespo, A. (2017). Determinantes de la continuidad en la contratación de la auditoría de forma voluntaria: evidencia para el caso de España. Revista de Contabilidad-Spanish Accounting Review, 20 (1), 63-72.

Park, J., Lee, M., \& Won, J. (1999). Audit Quality Analysis Using Discretionary Accruals. Accounting and Auditing Research, 35, 289-319.

Park, B.J. (2015). Client importance and earnings quality: An analysis of the moderating effect of managerial incentives for target beating versus auditors' incentives to avoid reputational losses and litigation. Spanish Journal of Finance and Accounting, 44(4), 1-31. doi:10.1080/02102412.2015. 1076634

Park, B.J. (2017). Auditors' economic incentives and the sensitivity of managerial pay to accounting performance. Australian Accounting Review, 27(4), 382-399.

Peasnell, K.V., Pope P.F., \& Young, S. (2005). Board Monitoring and Earnings Management: Do Outside Directors Influence Abnormal Accruals?. Journal of Business Finance \& Accounting, 32(7-8), 1311-1346.

Petersen, M. A. (2009). Estimating standard errors in finance panel data sets: Comparing approaches. Review of Financial Studies, 22(1), 435-480.

Proyecto de Real Decreto por el que se aprueba el Regla- mento de desarrollo de la Ley 22/2015, de 20 de julio, de Auditoría de Cuentas. Ministerio de Economía y Empresa, Instituto de Contabilidad y Auditoría de Cuentas, 2018.

Reitchel, K., \& Wang, D. (2010) National and office specific measures of auditor industry expertise and effects on audit quality. Journal of Accounting Research, 48 (3), 647-686.

Real Decreto 877/2015, de 2 de octubre, por el que se modifica el Real Decreto 1517/2011, de 31 de octubre, por el que se aprueba el Reglamento que desarrolla el Texto Refundido de la Ley de Auditoría de Cuentas, BOE nž 237.

Regulation (EU) No 537/2014 of the European Parliament and of the Council of 16 April 2014 on specific requirements regarding statutory audit of public-interest entities and repealing Commission Decision 2005/909/EC, Official Journal of the European Union L 158/77.

Reynolds, J.K., \& Francis, J.R. (2000). Does size matter? The influence of large clients on office-level auditor reporting decisions. Journal of Accounting and Economics, 30(3), 375400.

Sarbanes-Oxley Act (2002), Public Law 107-204, 116 Stat. 745, enacted July 30, 2002.

Simunic, D. A. (1980). The pricing of audit services: Theory and evidence. Journal of Accounting Research, 161-190.

Simunic, D. A., \& Stein, M. T. (1987), Product Differentiation in Auditing: Auditor Choice in the Market for Unseasoned New Issues, Vancouver, BC: The Canadian Certified General Accountants' Research Foundation.

Solomon, I., Shields, M.D., \& Whittington, O.R (1999). What do industry-specialist auditors know? Journal of Accounting Research, 37(1), 191-208.

Tsipouridou, M., \& Spathis, C. (2012). Earnings Management and the Role of Auditors in an Unusual IFRS Context: the Case of Greece. Journal of International Accounting, Auditing and Taxation, 21, 62-78.

Vander Bauwhede, H., \& Willekens, M. (2004). Evidence on (the Lack of) Audit-quality Differentiation in the Private Client Segment of the Belgian Audit Market. European Accounting Review, 13(3), 501-522.

Warfield, T.D., Wild, J.J., \& Wild, K.L. (1995). Managerial Ownership, Accounting Choices, and Informativeness of Earnings. Journal of Accounting and Economics, 20, 6191.

Yasar, A. (2013). Big Four Auditors' Audit Quality and Earnings Management: Evidence from Turkish Stock Market. International Journal of Business and Social Science, 4(17), 153-163.

\section{Appendix A: Measure of discretionary accruals}

Discretionary accruals are estimated using the cross sectional variation of the modified Jones model proposed by Dechow et al., (1995). First, we compute total accruals (TACR) as the change in non-cash current assets minus the change in operating current liabilities and depreciation and amortization expense, i.e.,

$$
\begin{gathered}
\text { TACR }_{T}=\Delta(\text { Current Assets }- \text { Cash })_{t} \\
-\Delta(\text { Current Liabilities }- \text { Short Term Debt })_{t} \\
- \text { Depreciation }_{t}
\end{gathered}
$$

We then regress TACR on two variables: the change in revenues net of the change in receivables (REV-REC); and gross property, plant and equipment (PPE). The book value of total assets of the previous period (TA) is used as a deflator to reduce heteroscedasticity. 
INSERTAR IMAGEN DEL FINAL DEL DOCUMENTO

BLINDED

This last equation is estimated for each industry at twodigit SIC level and fiscal year combination. The nondiscretionary accruals are the prediction values from the equation indicated above, while discretionary accruals are the residuals. 